\title{
DOKONANE ORAZ PROJEKTOWANE ZMIANY W POLSKIEJ REGULACJI DOTYCZĄCEJ RATOWNICTWA MEDYCZNEGO - WYBRANE ZAGADNIENIA
}

\section{Wstęp}

O istotnej roli ratownika medycznego nie trzeba nikogo przekonywać, należy natomiast zwrócić uwagę na zmiany w ustawie z dnia 8 września 2006 r. o Państwowym Ratownictwie Medycznym wprowadzone ustawą z dnia 25 września 2015 r. o zmianie ustawy o Państwowym Ratownictwie Medycznym, a także na treść projektu z dnia 14 października $2016 \mathrm{r}$. o zmianie ustawy o Państwowym Ratownictwie Medycznym oraz niektórych innych ustaw ${ }^{1}$, będącego aktualnie na etapie konsultacji społecznych. Zarówno już dokonane, jak i projektowane zmiany przewidziane przez polskiego ustawodawcę mają za przedmiot w szczególności nowe zadania ratownika medycznego, proces kształcenia przedstawicieli tego zawodu, jak i związaną z tym nową definicję pojęcia "pierwsza pomoc" oraz zagadnienia związane $\mathrm{z}$ funkcjonowaniem zespołów ratownictwa medycznego.

Na wstępie niniejszych rozważań należy wskazać, iż omawiane kwestie autorki podejmuja, dokonując porównania przepisów obecnie obowiązującej ustawy z dnia 8 września 2006 r. o Państwowym Ratownictwie

* Autorki są doktorantkami w Katedrze Prawa Cywilnego, Handlowego i Ubezpieczeniowego Wydziału Prawa i Administracji Uniwersytetu im. Adama Mickiewicza w Poznaniu; k.arciszewska@op.pl, wojcieszak-agnieszka@wp.pl.

${ }^{1}$ Ustawy z dnia 31 stycznia 1959 r. o cmentarzach i chowaniu zmarłych, ustawy z dnia 27 sierpnia 2005 r. - Prawo o szkolnictwie wyższym, ustawy z dnia 27 sierpnia 2004 r. o świadczeniach opieki zdrowotnej finansowanych ze środków publicznych, ustawy z dnia 18 sierpnia 2011 r. o bezpieczeństwie osób przebywających na obszarach wodnych, ustawy z dnia 18 sierpnia 2011 r. o bezpieczeństwie i ratownictwie w górach i na zorganizowanych terenach narciarskich. 
Medycznym zawierającej zmiany wprowadzone ustawą z dnia 25 września 2015 r. o zmianie ustawy o Państwowym Ratownictwie Medycznym (Dz.U. z 2016 r. poz. 1887; dalej „ustawa o PRM”), jak i wspomnianego już projektu z dnia 14 października 2016 r. o zmianie ustawy o Państwowym Ratownictwie Medycznym oraz niektórych innych ustaw.

\section{Wykonywanie zawodu ratownika medycznego}

Kluczową kwestią zdaje się być samo zagadnienie wykonywania zawodu ratownika medycznego. Zgodnie ze znowelizowanym art. 11 ust. 1 ustawy o PRM wykonywanie zawodu ratownika medycznego polega przede wszystkim na udzielaniu świadczeń zdrowotnych, w tym szczególnej grupy świadczeń medycznych, którymi są medyczne czynności ratunkowe podejmowane wobec osoby w stanie nagłego zagrożenia zdrowotnego. Zadaniem zawodowym ratownika medycznego jest także zabezpieczenie osób znajdujących się w miejscu zdarzenia oraz podejmowanie działań zapobiegających zwiększeniu liczby osób w stanie nagłego zagrożenia zdrowotnego, transportowanie osób w stanie nagłego zagrożenia zdrowotnego, udzielanie wsparcia psychicznego w sytuacji powodującej stan nagłego zagrożenia zdrowotnego, a także prowadzenie edukacji zdrowotnej i promocji zdrowia. Za wykonywanie zawodu ratownika medycznego, podobnie jak w przypadku lekarzy czy pielęgniarek, ustawa o PRM uznała także nauczanie zawodu ratownika medycznego, wykonywanie pracy na rzecz doskonalenia zawodowego ratowników medycznych i dyspozytorów medycznych, organizowanie i prowadzenie zajęć z zakresu pierwszej pomocy, kwalifikowanie pierwszej pomocy, medycznych czynności ratunkowych, jak również prowadzenie badań naukowych i prac rozwojowych w zakresie ratownictwa medycznego.

Warto również nadmienić, iż za wykonywanie zawodu ratownika uznane zostało również kierowanie i zarządzanie ratownikami medycznymi i dyspozytorami medycznymi, jak również zatrudnienie czy też pełnienie służby na stanowiskach administracyjnych, na których wykonuje się czynności związane z przygotowaniem, organizowaniem lub nadzorem nad udzielaniem świadczeń zdrowotnych $\mathrm{w}$ zakresie ratownictwa medycznego. Ustawa o PRM nakłada na ratowników medycznych obowiązek działania zgodnie ze wskazaniami aktualnej wiedzy medycznej oraz należytą starannością, analogicznie jak zobowiązani są do tego lekarze, pielęgniarki i położne, diagności laboratoryjni, fizjoterapeuci czy 
też farmaceuci². Jako samodzielny zawód medyczny ratownik medyczny zyskuje również swobodę $\mathrm{w}$ korzystaniu z wiedzy medycznej w postaci standardów, wytycznych, badań i publikacji naukowych ${ }^{3}$. Wiedza ta musi mieć jednak walor aktualności, co w ewentualnych sprawach sądowych będzie przedmiotem oceny sądu z wykorzystaniem opinii powołanych przez sąd biegłych z zakresu ratownictwa medycznego ${ }^{4}$.

Należy w tym miejscu zasygnalizować, iż ustawa o PRM przyznaje prawo do tego, by ratownik medyczny po dokonaniu oceny stanu pacjenta mógł nie podejmować lub odstąpić od medycznych czynności ratunkowych albo od udzielania świadczeń zdrowotnych, jeżeli nie spowoduje to niebezpieczeństwa utraty życia, ciężkiego uszkodzenia ciała lub ciężkiego rozstroju zdrowia. Ratownik medyczny zobowiązany został do uzasadnienia i odnotowania w dokumentacji medycznej przyczyny niepodjęcia lub odstąpienia od medycznych czynności ratunkowych albo udzielenia świadczeń zdrowotnych ${ }^{5}$. Prawo do niepodejmowania czy odstępowania od medycznych czynności ratunkowych nie jest równoznaczne z prawem do stwierdzenia zgonu, do czego ratownik medyczny nie został upoważniony w polskim prawie.

Kolejnym postulatem środowiska ratowników medycznych zrealizowanym w nowelizacji ustawy o PRM jest prawo do wglądu do dokumentacji medycznej pacjenta. Dotychczas ratownicy medyczni byli pominięci $\mathrm{w}$ przepisach ustawy $\mathrm{z}$ dnia 6 listopada 2008 r. o prawach pacjenta i Rzeczniku Praw Pacjenta. Stwarzało to dla nich absurdalną i niebezpieczną sytuację, gdyż do prawidłowego rozpoznania stanu zagrożenia zdrowia/życia niejednokrotnie konieczne jest pozyskanie informacji o przebiegu dotychczasowego leczenia pacjenta. Dlatego też warto wskazać, iż ratownik medyczny nabył prawo do uzyskiwania od lekarzy, felczerów oraz pielęgniarek i położnych informacji o stanie zdrowia pacjenta, rozpoznaniu, proponowanych metodach diagnostycznych, leczniczych, rehabilitacyjnych, zapobiegawczych i dających się przewidzieć następstwach podejmowanych świadczeń zdrowotnych w zakresie, $\mathrm{w}$ jakim jest to niezbędne do wykonywania medycznych świadczeń ratunkowych ${ }^{6}$. Co istotne, ratownicy medyczni zostali zobowiązani do informowania pacjenta o przysługujących mu prawach, a to wiąże się bez-

2 Art. 11 ust. 2 ustawy o PRM.

${ }^{3}$ S. Poździoch, Ustawa o Państwowym Ratownictwie Medycznym. Komentarz, Warszawa 2015, s. 65.

${ }^{4}$ Tamże, s. 67.

${ }^{5}$ Art. 11 ust. 10 ustawy o PRM.

${ }^{6}$ Art. 11 ust. 5 ustawy o PRM. 
pośrednio z koniecznością biegłej znajomości zagadnień prawnych oraz paramedyków wynikających w szczególności z ustawy z dnia 6 listopada 2008 r. o prawach pacjenta i Rzeczniku Praw Pacjenta (tekst jedn., Dz.U. z 2016 r. poz. 823), ustawy z dnia 19 sierpnia 1994 r. o ochronie zdrowia psychicznego (tekst jedn., Dz.U. z 2016 r. poz. 546), ustawy z dnia 5 grudnia 2008 r. o zapobieganiu oraz zwalczaniu zakażeń i chorób zakaźnych u ludzi (tekst jedn., Dz.U. z 2016 r. poz. 1866). Ratownikom medycznym $\mathrm{w}$ podstawowym zespole ratownictwa medycznego przypisany został ponadto obowiązek udzielania pacjentowi lub jego przedstawicielowi ustawowemu albo osobie wskazanej przez pacjenta informacji o stanie zdrowia pacjenta $\mathrm{w}$ zakresie związanym z podejmowaniem medycznych czynności ratunkowych. W nowych przepisach ratownicy medyczni zostali wprost zobowiązani do zachowania tajemnicy zawodowej. Jest to znaczące novum, które zdaniem autorek należy oceniać pozytywnie choćby z uwagi na istotne dla zdrowia i życia pacjenta czynności podejmowane przez ratownika medycznego. Jednakże należy wyjaśnić, iż w zakresie obowiązku zachowania tajemnicy zawodowej ustawodawca zastosował pewne ograniczenie, wyłączając spod tego obowiązku przekazywanie informacji osobom upoważnionym przez pacjenta $\mathrm{w}$ sytuacji zwolnienia przez sąd lub prokuratora, podejrzenia przemocy, realnego zagrożenia dla życia i zdrowia innych osób ze strony pacjenta ${ }^{8}$. W tym też kontekście należy wskazać na treść art. 13 i 14 ustawy z dnia 6 listopada 2008 r. o prawach pacjenta i Rzeczniku Praw Pacjenta (tekst jedn., Dz.U. z 2016 r. poz. 186). W myśl art. 13 pacjent ma prawo do zachowania tajemnicy przez osoby wykonujące zawód medyczny, w tym udzielające mu świadczeń zdrowotnych, informacji z nim związanych, a uzyskanych w związku z wykonywaniem zawodu medycznego. Nie ulega bowiem wątpliwości, iż ratownik medyczny posiada status osoby wykonującej zawód medyczny. Analizując omawianą regulację, należy - w ocenie autorek - podzielić zawarty $\mathrm{w}$ doktrynie pogląd, iż nie zawsze będzie się to odnosiło do osoby, do której pacjent zwrócił się o udzielanie świadczenia zdrowotnego, tajemnica wiąże bowiem także innych przedstawicieli zawodu i innych grup zawodów opieki zdrowotnej, którzy od depozytariusza sekretu uzyskali informacje niejawne w związku z wykonywanymi czynnościami zawodowymi ${ }^{9}$. W tej mierze istotny jest również fakt, iż

\footnotetext{
7 A. Kopta, Kwalifikowana pierwsza pomoc, Warszawa 2016, s. 89.

8 Tamże, s. 92.

9 D. Karkowska, Ustawa o prawach pacjenta i Rzeczniku Praw Pacjenta. Komentarz, Warszawa 2015, s. 56.
} 
informacje uzyskane w związku z wykonywaniem zawodu medycznego dotyczą szeroko rozumianego zdrowia pacjenta, ale równie dobrze moga dotyczyć życia osobistego czy rodzinnego pacjenta lub sfery jego aktywności społecznej czy publicznej, ponieważ o granicach dyskrecji będzie decydować przede wszystkim sposób uzyskania określonych informacji, a nie wyłącznie ich zawartość i treść ${ }^{10}$. W myśl zaś art. 14 ust. 1 ustawy o prawach pacjenta i Rzeczniku Praw Pacjenta w celu realizacji prawa, o którym mowa w art. 13, osoby wykonujące zawód medyczny są obowiązane zachować $\mathrm{w}$ tajemnicy informacje związane z pacjentem, w szczególności ze stanem jego zdrowia. Ustęp 2 oraz ust. 2a przytoczonego artykułu zawiera natomiast wyliczenie okoliczności, przy których wystąpieniu wyłączone jest stosowanie art. 1 cytowanej ustawy. Jedną z nich jest zawarta w odrębnej ustawie dyspozycja. W tym też zakresie warto nadmienić, iż na mocy art. 266 ustawy z dnia 6 czerwca 1997 r. - Kodeks karny (tekst jedn., Dz.U. z 2016 r. poz. 1137, dalej „k.k.”) osoby wykonujące zawód medyczny oskarżone w procesie karnym mogą ujawnić wiadomości, które są objęte tajemnicą zawodowa, służbową i funkcjonalną, bez konsekwencji narażenia się na dodatkową odpowiedzialność karną. Dopuszcza się taką możliwość tylko $\mathrm{w}$ takim zakresie, w jakim jest to niezbędne do wyjaśnienia okoliczności danej sprawy. Okoliczności te muszą mieć zawsze związek z toczącą się sprawą ${ }^{11}$. Należy zwrócić uwagę, iż obowiązek zachowania tajemnicy zawodowej uznaje się za wyłączony również $\mathrm{w}$ związku z ustawowym i powszechnym obowiązkiem niezwłocznego powiadomienia organów powołanych do ścigania o przygotowaniu, usiłowaniu lub dokonywaniu następujących rodzajów przestępstw, określonych w art. 240 k.k.: ludobójstwo (art. 118 k.k.), usiłowanie pozbawienia niepodległości RP, obalenie przemocą ustroju (art. 127 k.k.), zamach stanu (art. 128 k.k.), szpiegostwo (art. 130 k.k.), zamach na Prezydenta Rzeczypospolitej Polskiej (art. 134 k.k.), zamach na jednostkę sił zbrojnych (art. 140 k.k.), zabójstwo (art. 148 k.k.), sprowadzenie katastrofy (art. 163 k.k.), porwanie samolotu (art. 166 k.k.) lub wzięcie zakładnika (art. 252 k.k.) ${ }^{12}$. Jednakże w tym kontekście autorki pragną jedynie zasygnalizować treść art. $180 \S 1$ zd. 1 ustawy z dnia 6 czerwca 1997 r. - Kodeks postępowania karnego (tekst jedn., Dz.U. z 2016 r. poz. 1749), zgodnie z którym osoby obowiązane do zachowania w tajemnicy informacji niejawnych o klauzuli tajności „zastrzeżone” lub „poufne” lub tajemnicy związanej z wykony-

\footnotetext{
10 Tamże, s. 60.

11 Tamże, s. 62.

12 Tamże, s. 64.
} 
waniem zawodu lub funkcji mogą odmówić zeznań co do okoliczności, na które rozciąga się ten obowiązek, chyba że sąd lub prokurator dla dobra wymiaru sprawiedliwości zwolni te osoby od obowiązku zachowania tajemnicy, jeżeli ustawy szczególne nie stanowią inaczej.

Nadto art. 11 ustawy o PRM, w ust. 12 zawiera delegację do wydania rozporządzenia określającego szczegółowy zakres: medycznych czynności ratunkowych, które mogą być udzielane przez ratownika medycznego samodzielnie lub pod nadzorem lekarza systemu świadczeń zdrowotnych innych niż medyczne czynności ratunkowe, które mogą być udzielane przez ratownika medycznego samodzielnie lub na zlecenie - kierując się zakresem wiedzy i umiejętności nabytych w ramach kształcenia przed- i podyplomowego.

Wskazania wymaga, iż nowe przepisy wprowadzają dodatkowe obowiązki w obszarze dokumentowania świadczeń wykonywanych przez ratowników medycznych $\mathrm{w}$ ramach ratownictwa górskiego, narciarskiego, ratownictwa wodnego, górniczego, morskiej służby poszukiwania i ratownictwa, w jednostkach podległych Ministrowi Obrony Narodowej niebędących podmiotami leczniczymi oraz $\mathrm{w}$ jednostkach ochrony przeciwpożarowej, na lotniskach, przy zabezpieczeniu medycznym imprez masowych, w transporcie sanitarnym. Dokumentowanie świadczeń zdrowotnych udzielanych przez ratownika medycznego prowadzone będzie $\mathrm{w}$ karcie indywidualnej ratownika medycznego ${ }^{13}$. Co warte zasygnalizowania, projekt ustawy z dnia 14 października 2016 r. zakłada dodanie ustępu 13, na mocy którego Minister Obrony Narodowej uzyska delegację do określenia $\mathrm{w}$ drodze rozporządzenia szczegółowego zakresu świadczeń zdrowotnych, które mogą być podejmowane przez ratownika medycznego wykonującego zadania zawodowe w jednostkach podległych Ministrowi Obrony Narodowej niebędących podmiotami leczniczymi.

Nakreślając zagadnienie wykonywania zawodu przez ratowników medycznych, należy również wyjaśnić kwestię, która nierozerwalnie się z tym tematem łączy - udzielanie pierwszej pomocy. W art. 4 ustawy o PRM ustawodawca wprowadził nową definicję pojęcia „pierwsza pomoc”. W myśl artykułu, o którym mowa w zdaniu poprzednim, kto zauważy osobę znajdującą się $\mathrm{w}$ stanie nagłego zagrożenia zdrowotnego lub jest świadkiem zdarzenia powodującego taki stan, w miarę posiadanych możliwości ma obowiązek: niezwłocznego podjęcia działań zmierzających do skutecznego powiadomienia o tym podmiotów ustawowo powołanych do niesienia po-

${ }^{13}$ Zgodnie z treścią art. 11 ust. 7 ustawy o PRM karta indywidualna ratownika medycznego zawiera dane, o których mowa w art. 25 ustawy z dnia 6 listopada 2008 r. o prawach pacjenta i Rzeczniku Praw Pacjenta. 
mocy lub centrum powiadamiania ratunkowego, udzielenia pierwszej pomocy, chyba że spowoduje to narażenie osoby udzielającej tej pomocy lub innej osoby na niebezpieczeństwo utraty życia lub uszczerbku na zdrowiu.

Omawiając tematykę wykonywania zawodu przez ratowników medycznych, należy wskazać na zagadnienia związane z procesem kształcenia tych osób zawarte w znowelizowanej ustawie o PRM, jak i te zawarte $\mathrm{w}$ projekcie z dnia 14 października $2016 \mathrm{r}$. Zgodnie bowiem z brzmieniem art. 12 ust. 1 ustawy o PRM ratownik medyczny ma prawo i obowiązek doskonalenia zawodowego w różnych formach kształcenia. Dla porządku należy w tym miejscu wyjaśnić, iż prawo i obowiązek ustawicznego kształcenia charakterystyczne jest dla zawodów medycznych jako tych, które potocznie określa się mianem „zawodów ciągłego kształcenia”. Dlatego też warto wskazać, iż projekt ustawy z dnia 14 października $2016 \mathrm{r}$. zakłada uzupełnienie art. 12 ustawy o PRM o nowe przepisy stanowiące swoiste doprecyzowanie istniejącej regulacji taktujące o tym, że ratownik medyczny ma prawo i obowiązek indywidualnego rozwoju zawodowego przez aktualizację wiedzy i umiejętności w ramach kształcenia podyplomowego i doskonalenia zawodowego. Ponadto, zgodnie z projektowanymi zmianami, ratownik medyczny ma prawo stałego aktualizowania wiedzy i umiejętności przez uczestnictwo w następujących formach kształcenia podyplomowego: kurs kwalifikacyjny i kurs specjalistyczny oraz formach doskonalenia zawodowego: kurs doskonalący oraz samokształcenie. Co istotne, projektowane zmiany zakładaja, iż ratownik medyczny winien przedstawić podmiotowi, u którego wykonuje zawód, dokumenty poświadczające realizację obowiązku kształcenia podyplomowego, o którym mowa w zdaniu poprzednim. Warto także w tym miejscu nadmienić, iż pielęgniarka systemu ${ }^{14}$ jest uprawniona do wykonywania medycznych czynności ratunkowych niewykraczających poza zakres określony w przepisach o zawodach pielęgniarki i położnej. Nadto planowane zmiany wprowadzają regulacje w przedmiocie uprawnień do prowadzenia kursu doskonalącego, w szczególności uprawnień podmiotów ubiegających się o uzyskanie wpisu na listę podmiotów uprawnionych do prowadzenia ww. kursu. Istotne zmiany w zakresie doskonalenia zawodowego ratowników medycznych wprowadzone zostały przez polskiego ustawodawcę w ustawie z dnia 9 października 2015 r. o zmianie ustawy o systemie informacji w ochronie zdrowia oraz niektórych innych ustaw (Dz.U. poz. 1991

${ }^{14}$ Zgodnie z art. 1 ustawy o PRM: w celu realizacji zadań państwa polegających na zapewnieniu pomocy każdej osobie znajdującej się w stanie nagłego zagrożenia zdrowotnego tworzy się system Państwowe Ratownictwo Medyczne, zwany dalej systemem. 
ze zm.), w art. 9 tej tego aktu prawnego dotyczące w szczególności Państwowego Egzaminu Ratowników Medycznych (PERM). Wspomniana nowela w sposób dokładny i niemal wyczerpujący reguluje w szczególności kwestie kwalifikacji kandydatów do ww. egzaminu, przebiegu egzaminu, składu i działania komisji egzaminacyjnej, skutków, jakie niesie za sobą złożenie egzaminu $\mathrm{z}$ wynikiem pozytywnym oraz negatywnym. Autorki ograniczą się do wskazania, iż z możliwością przystąpienia do omawianego egzaminu wiąże się konieczność założenia konta w Systemie Monitorowania Kształcenia Pracowników Medycznych, o którym mowa w art. 30 ust. 1 ustawy z dnia 28 kwietnia 2011 r. o systemie informacji w ochronie zdrowia. Co istotne, w myśl noweli wyniki Państwowego Egzaminu Ratowników Medycznych są udostępniane za pomocą systemu, o którym mowa w zdaniu poprzednim, uczelniom wyższym, w zakresie studentów i absolwentów ich wydziałów. Wspomniana nowela, w art. 10g zawiera delegację dla ministra właściwego do spraw zdrowia do określenia w drodze rozporządzenia wzorów dokumentów oraz działań związanych z przeprowadzeniem wspomnianego egzaminu oraz weryfikacją jego wyników. Ponadto warto wskazać na wyartykułowany w omawianej noweli obowiązek ratownika medycznego do odbycia przeszkolenia w sytuacji, gdy zaistnieją wskazane w art. $10 \mathrm{~h}$ ust. 1 okoliczności. Ponadto na mocy art. 12 ust. 1 ratownik medyczny ma obowiązek przedstawienia wojewodzie właściwemu ze względu na miejsce zamieszkania ratownika medycznego do wglądu karty doskonalenia zawodowego niezwłocznie po zakończeniu danego okresu edukacyjnego, w terminie nie dłuższym niż 30 dni od dnia zakończenia danego okresu edukacyjnego. Wprowadzone przez ustawodawcę zmiany bez wątpienia jeszcze silniej akcentują konieczność ustawicznego kształcenia ratowników medycznych.

Nie sposób pominąć również faktu, iż regulacje uwzględnione w projekcie z dnia 14 października 2016 r. zakładają wprowadzenie e-konsultacji, a zatem konsultacji kierującego akcją medyczną z lekarzem konsultantem ratownictwa lub lekarzem SOR za pośrednictwem systemów teleinformatycznych lub systemów łączności, w szczególności przez przekaz na odległość danych medycznych. W kontekście powyższego należy wskazać, iż nowelizacja zakłada utworzenie stanowiska lekarza konsultanta dla zespołów ratownictwa medycznego.

Co znaczące, od 1 stycznia 2016 r. zawód ratownika medycznego można w pełni wykonywać w: podmiotach leczniczych ${ }^{15}$, w ramach ratownic-

${ }^{15}$ Ustawa o PRM nie ogranicza się jedynie do szpitalnych oddziałów ratunkowych czy izb przyjęć. 
twa górniczego, w ramach morskiej służby poszukiwania i ratownictwa, w jednostkach ochrony przeciwpożarowej włączonych do krajowego systemu ratowniczo-gaśniczego ${ }^{16}$, na lotniskach, przy zabezpieczeniu medycznym imprez masowych ${ }^{17}$, przy wykonywaniu transportu sanitarnego, w izbach wytrzeźwień, na stanowisku dyspozytora. Potwierdzone zostało nadane już wcześniej prawo ratowników medycznych do wykonywania medycznych czynności ratunkowych $\mathrm{w}$ ramach ratownictwa wodnego ${ }^{18}$ oraz $\mathrm{w}$ ramach ratownictwa górskiego i narciarskiego ${ }^{19}$. W ustawie o PRM brak jest jednak usankcjonowania wykonywania zawodu ratownika medycznego m.in. w służbie policyjnej, straży granicznej, służbie więziennej, Biurze Ochrony Rządu, Centralnym Biurze Antykorupcyjnym, Agencji Bezpieczeństwa Wewnętrznego, a także powołanej niedawno do życia w Polsce Służbie Poszukiwania i Ratownictwa Lotniczego (ASAR).

Dla właściwego zrozumienia analizowanych w niniejszym artykule kwestii należy wskazać na fakt, iż zgodnie z brzmieniem art. 32 ust. 1 ustawy o PRM jednostkami systemu są szpitalne oddziały ratunkowe oraz zespoły ratownictwa medycznego, $\mathrm{w}$ tym lotnicze zespoły ratownictwa medycznego, na których świadczenia zawarto umowy o udzielaniu świadczeń opieki zdrowotnej. Z kolei zespoły ratownictwa medycznego dzielą się na zespoły specjalistyczne, w skład których wchodzą co najmniej trzy osoby uprawnione do wykonywania medycznych czynności ratunkowych, w tym lekarz systemu oraz pielęgniarka systemu lub ratownik medyczny, oraz zespoły podstawowe, w skład których wchodzą co najmniej dwie osoby uprawnione do wykonywania medycznych czynności ratunkowych, w tym pielęgniarka systemu lub ratownik medyczny. W kontekście powyżej przytoczonego brzmienia ww. przepisu istotną zmianę stanowi regulacja zawarta w projekcie $\mathrm{z}$ dnia 14 października 2016 r. zakładająca istnienie podstawowych zespołów ratownictwa medycznego, w skład których wchodzą trzy osoby uprawnione do wykonywania medycznych czynności ratunkowych, będące ratownikiem medycznym lub pielęgniarką systemu, z których co najmniej jedna posiada ważne zaświadczenie o ukończeniu kursu specjalistycznego. Nadto wspomniany projekt zakłada utworzenie motocyklowych zespołów ratownictwa medycznego funkcjonujących w okresie od 1 maja do 30 wrześ-

${ }^{16}$ Jednak tylko w zakresie ćwiczeń, szkoleń oraz działań w strefie zagrożenia.

17 Jednak wyłącznie $w$ ramach podmiotu leczniczego.

18 Nadane przez ustawę z dnia 18 sierpnia 2011 r. o bezpieczeństwie osób przebywających na obszarach wodnych.

${ }^{19}$ Ustanowione w ustawie z dnia 18 sierpnia 2011 r. o bezpieczeństwie i ratownictwie w górach i na zorganizowanych terenach narciarskich. 
nia i nie dłużej niż 12 godzin na dobę, w skład których wchodziłaby osoba wykonująca zadania $\mathrm{w}$ ramach stosunku pracy $\mathrm{u}$ dysponenta jednostki ${ }^{20}$, w tym ratownik medyczny lub pielęgniarka systemu, posiadający ważne zaświadczenie o ukończeniu kursu specjalistycznego. Nadto, zgodnie z projektowanymi zmianami, art. 32 ust. 1 pkt 2 ma stanowić o tym, iż zespoły ratownictwa medycznego, w tym zespoły ratownictwa wchodzące $\mathrm{w}$ skład podmiotu leczniczego będącego samodzielnym publicznym zakładem opieki zdrowotnej albo jednostką budżetowa, albo spółką kapitałową, w której co najmniej 51\% udziałów albo akcji należy do Skarbu Państwa lub jednostek samorządu terytorialnego lub uczelni medycznej.

\section{Finansowanie i funkcjonowanie zespołów ratownictwa medycznego}

Niejako na marginesie niniejszych rozważań należy wskazać na dwie kwestie niezwiązane bezpośrednio z wykonywaniem zawodu ratownika medycznego, lecz dotyczące ratownictwa medycznego. Pierwszą z nich jest zagadnienie finansowania jednostek systemu. $W$ tym miejscu należy wskazać na fakt, iż zgodnie z brzmieniem art. 21 ust. 1 ustawy o PRM system działa na obszarze województwa na podstawie wojewódzkiego planu działania systemu sporządzanego przez wojewodę. Co istotne, zatwierdzony plan jest podstawą do zawierania przez dyrektorów oddziałów wojewódzkich Narodowego Funduszu Zdrowia umów na wykonywanie medycznych czynności ratunkowych, jednakże z zastrzeżeniem art. 49 ust. 2 ustawy o PRM. Jak wynika zaś z art. 49 ust. 1 ww. ustawy, wojewoda powierza przeprowadzenie postępowania o zawarcie umów z dysponentami zespołów ratownictwa medycznego na wykonywanie zadań zespołów ratownictwa medycznego, zawieranie, rozliczanie i kontrolę wykonywania tych umów dyrektorowi właściwego oddziału wojewódzkiego Narodowego Funduszu Zdrowia. Ustęp 2 wskazanego $\mathrm{w}$ zdaniu poprzednim artykułu stanowi natomiast, iż dyrektor oddziału wojewódzkiego Narodowego Funduszu Zdrowia zawiera umowy, o których mowa w ust. 1, na rejony operacyjne, na podstawie planu oraz w ramach środków przewidzianych w budżecie państwa, w części, której

${ }^{20}$ Zgodnie z brzmieniem art. 3 pkt 1 ustawy o PRM: dysponent jednostki, to podmiot leczniczy w rozumieniu przepisów o działalności leczniczej, w skład którego wchodzi jednostka systemu, o której mowa w art. 32 ust. 1 ustawy o PRM. 
dysponentem jest wojewoda, ujętych w planie finansowym Narodowego Funduszu Zdrowia. Istotne jest, iż do postępowania w sprawie zawarcia umów, o których mowa w art. 49 ust. 1 ustawy o PRM, ich zawierania, rozliczania i kontroli stosuje się odpowiednio przepisy ustawy z dnia 27 sierpnia 2004 r. o świadczeniach opieki zdrowotnej finansowanych ze środków publicznych (tekst jedn., Dz.U. z 2016 r. poz. 1793) ${ }^{21}$.

Niniejsze rozważania należy uzupełnić o brzmienie art. 46 ust. 1 ustawy o PRM, zgodnie z którym zadania zespołów ratownictwa medycznego, z wyłączeniem lotniczych zespołów ratownictwa medycznego, są finansowane z budżetu państwa z części, których dysponentami są poszczególni wojewodowie. W myśl art. 48 ust. 1 ustawy o PRM działalność lotniczych zespołów ratownictwa medycznego jest $\mathrm{z}$ kolei finansowana z budżetu państwa, z części, której dysponentem jest minister właściwy do spraw zdrowia.

Celem lepszego zrozumienie omawianych zagadnień należy wskazać, iż przepisy ustawy z dnia 27 sierpnia 2004 r. o świadczeniach opieki zdrowotnej finansowanych ze środków publicznych zawierają wyczerpującą regulację $\mathrm{w}$ przedmiocie zawierania umów o udzielanie świadczeń opieki zdrowotnej ${ }^{22}$. Jak wskazują komentatorzy, umowa o udzielanie świadczeń opieki zdrowotnej ma charakter umowy wzajemnej, odpłatnej, dwustronnie zobowiązującej, w której każda ze stron jest jednocześnie wierzycielem i dłużnikiem ${ }^{23}$. Zawarcie bowiem przez Fundusz umowy o udzielanie świadczeń opieki zdrowotnej służy realizacji publicznoprawnego obowiązku zapewnienia opieki zdrowotnej ubezpieczonym ${ }^{24}$. Z powyższego wynika, iż świadczenia opieki zdrowotnej realizowane są przez świadczeniodawcę (podmiot leczniczy) na rzecz świadczeniobiorcy (pacjent), zaś Narodowy Fundusz Zdrowia jest w takim układzie jedynie płatnikiem. Co istotne, przepis art. 132 ust. 2 ustawy z dnia 27 sierpnia 2004 r. o świadczeniach opieki zdrowotnej finansowanych ze środków publicznych wskazuje, że umowa o udzielanie świadczeń opieki zdrowotnej może być zawarta wyłącznie ze świadczeniodawca, który został wybrany do udzielania świadczeń opieki zdrowotnej na zasadach określonych w dziale VI ustawy. Oznacza to konieczność zastosowania procedury konkursu ofert lub rokowań wobec wszystkich potencjalnych

${ }^{21}$ Art. 49 ust. 5 ustawy o PRM.

${ }^{22}$ T. Zimna, Zawieranie umów o udzielanie świadczeń opieki zdrowotnej, Warszawa 2015, s. 98.

${ }^{23}$ A. Pietraszewska-Macheta, Ustawa o świadczeniach opieki zdrowotnej finansowanych ze środków publicznych, Warszawa 2015, s. 935-936.

24 Tamże, s. 940. 
podmiotów ubiegających się o zawarcie umowy o udzielanie świadczeń opieki zdrowotnej ze środków publicznych ${ }^{25}$.

Na gruncie przytoczonych przepisów konieczne zdaje się być stwierdzenie, iż w odniesieniu do świadczeń opieki zdrowotnej z zakresu ratownictwa medycznego ustawodawca polski niejako różnicuje podmiot odpowiedzialny za zawarcie i rozliczenie przedmiotowych świadczeń. O ile w przypadku umowy o udzielane świadczeń opieki zdrowotnej, uregulowanej przepisami ustawy z dnia 27 sierpnia 2004 r. o świadczeniach opieki zdrowotnej finansowanych ze środków publicznych, stroną tych umów jest dyrektor właściwego oddziału wojewódzkiego Narodowego Funduszu Zdrowia, o tyle w odniesieniu do świadczeń ratownictwa medycznego dyrektor oddziału wojewódzkiego Funduszu przeprowadza postępowania o zawarcie umów na wykonywanie zadań zespołów ratownictwa medycznego na podstawie delegacji wojewody. Co istotne, środki na finansowanie wskazanych w zdaniu poprzednim umów wojewoda przekazuje Narodowemu Funduszowi Zdrowia w formie dotacji celowej, $\mathrm{w}$ trybie i na zasadach określonych $\mathrm{w}$ przepisach o finansach publicznych w celu zapewnienia finansowania zadań zespołów ratownictwa medycznego na terenie właściwego oddziału wojewódzkiego Narodowego Funduszu Zdrowia ${ }^{26}$. Niniejsze wiedzie do wniosku, iż w myśl projektowanych zmian do 1 stycznia 2018 r. nastąpić ma zawieranie umów wyłącznie z podmiotami leczniczymi utworzonymi z całkowitym lub większościowym udziałem kapitału publicznego, co doprowadzi do odejścia od wyłaniania dysponentów zespołów ratownictwa medycznego w trybie konkursowym na rzecz zawierania umów z dysponentami wskazanymi przez wojewodów w planie działania systemu, po zasięgnięciu opinii właściwych jednostek samorządu terytorialnego.

Drugą kwestia, pośrednio związaną z wykonywaniem zawodu ratownika medycznego, jest transport sanitarny pacjenta. Zgodnie $\mathrm{z}$ art. 33 ust. 1 ustawy o PRM szpitalny oddział ratunkowy, centrum urazowe, centrum urazowe dla dzieci oraz jednostka organizacyjna szpitala wyspecjalizowana w zakresie udzielania świadczeń zdrowotnych niezbędnych dla ratownictwa medycznego niezwłocznie udzielają niezbędnych świadczeń opieki zdrowotnej pacjentowi urazowemu, pacjentowi urazowemu dziecięcemu albo osobie w stanie nagłego zagrożenia zdrowotnego. Zgodnie z ust. 2 cytowanego artykułu w razie konieczności szpital, w którym znajduje się szpitalny oddział ratunkowy, centrum urazowe, centrum urazo-

${ }^{25}$ A. Sieńko, Prawo ochrony zdrowia, Warszawa 2008, s. 87.

26 Art. 49 ust. 3 ustawy o PRM. 
we dla dzieci lub jednostka wyspecjalizowana szpitala w zakresie udzielania świadczeń zdrowotnych niezbędnych dla ratownictwa medycznego, zapewnia niezwłoczny transport sanitarny pacjenta urazowego, pacjenta urazowego dziecięcego albo osoby w stanie nagłego zagrożenia zdrowotnego do najbliższego przedsiębiorstwa podmiotu leczniczego udzielającego świadczeń opieki zdrowotnej w odpowiednim zakresie. Zgodnie zaś $\mathrm{z}$ art. 45 ust. 1 ustawy o PRM w przypadku, gdy u osoby w stanie nagłego zagrożenia zdrowotnego zostanie stwierdzony stan, który zgodnie ze standardami postępowania, o których mowa w art. 43, wymaga transportu z miejsca zdarzenia bezpośrednio do szpitala, w którym znajduje się centrum urazowe lub centrum urazowe dla dzieci albo do jednostki organizacyjnej szpitala wyspecjalizowanej w zakresie udzielania świadczeń zdrowotnych niezbędnych dla ratownictwa medycznego, wskazanego przez dyspozytora medycznego lub lekarza koordynatora ratownictwa medycznego. W przypadku transportu poza obszar działania dyspozytorni medycznej transport koordynuje lekarz koordynator ratownictwa medycznego ${ }^{27}$. Transport międzyszpitalny dotyczy natomiast przewozów międzyszpitalnych pacjentów w stanie nagłego zagrożenia zdrowotnego ze szpitalnego oddziału ratunkowego lub szpitala, o którym mowa w art. 3 pkt 2 ustawy z dnia 19 sierpnia 1994 r. o ochronie zdrowia psychicznego (Dz.U. z 2016 r. poz. 546, 960 i 1245), do innego szpitala właściwego ze względu na stan zdrowia pacjenta, jeżeli nie jest dostępny inny, odpowiedni środek transportu sanitarnego, a stan zdrowia pacjenta wymaga niezwłocznego transportu sanitarnego. Zgodnie z treścią art. 3 pkt 2 ustawy z dnia 19 sierpnia 1994 r. o ochronie zdrowia psychicznego ilekroć przepisy niniejszej ustawy stanowią o szpitalu psychiatrycznym, odnosi się to również do oddziału psychiatrycznego w szpitalu ogólnym, kliniki psychiatrycznej, sanatorium dla osób z zaburzeniami psychicznymi, innego zakładu leczniczego podmiotu leczniczego w rozumieniu przepisów o działalności leczniczej sprawującego całodobową opiekę psychiatryczną lub odwykowa, niezależnie od podmiotu, który je tworzy lub utrzymuje.

\section{Wnioski}

Analiza obowiązujących przepisów ustawy z dnia 8 września 2006 r. o Państwowym Ratownictwie Medycznym, jak i zapisów wskazanych

${ }^{27}$ A. Kopta, Kwalifikowana..., s. 115. 
$\mathrm{w}$ projekcie zmiany ww. ustawy czyni w ocenie autorek uzasadnionym twierdzenie, iż zmiany te zmierzają z jednej strony do zwiększenia odpowiedzialności ratowników medycznych za wykonywane czynności, z drugiej zaś strony dostarczają skutecznych narzędzi służących rzetelnemu niesieniu pomocy przez ratowników medycznych. Regulacje dotyczące choćby konieczności zachowania tajemnicy zawodowej czy prowadzenia karty indywidualnej ratownika medycznego stanowią właściwy sposób zabezpieczenia praw pacjenta oraz podkreślają istotną rolę ratownika medycznego w procesie ratowania ludzkiego życia. Należy również pozytywnie ocenić projektowane zmiany wprowadzające możliwość przeprowadzenia konsultacji z wykorzystaniem infrastruktury informatycznej (e-konsultacje), zarówno z punktu widzenia ratowników udzielających świadczeń, jak i coraz powszechniejszego wykorzystania środków informatycznych $w$ medycynie. Istotne jest także zaakcentowanie praktycznego wymiaru, jaki z pewnością będzie niosło za sobą stosowanie nowej definicji pierwszej pomocy. Kontestując wprowadzone i planowane zmiany, należy przychylić się do postulatu środowiska ratowników medycznych, by zwiększyć ochronę przedstawicieli tego zawodu medycznego w stopniu, $\mathrm{w}$ jakim jest ona zapewniona funkcjonariuszom publicznym.

Słowa kluczowe: NFZ, ratownictwo medyczne, zdrowie, świadczenia zdrowotne.

\section{Bibliografia}

Karkowska D., Ustawa o prawach pacjenta i Rzeczniku Praw Pacjenta. Komentarz, Warszawa 2015.

Kopta A., Kwalifikowana pierwsza pomoc, Warszawa 2016.

Pietraszewska-Macheta A., Ustawa o świadczeniach opieki zdrowotnej finansowanych ze środków publicznych, Warszawa 2015.

Poździoch S., Ustawa o Państwowym Ratownictwie Medycznym. Komentarz, Warszawa 2013.

Sieńko A., Prawo ochrony zdrowia, Warszawa 2008.

Zimna T., Zawieranie umów o udzielanie świadczeń opieki zdrowotnej, Warszawa 2015. 


\section{CHANGES PROPOSED AND IMPLEMENTED \\ IN POLISH REGULATIONS CONCERNING EMERGENCY MEDICAL SERVICES - SELECTED ISSUES}

\section{$S \mathbf{u ~ m ~ m ~ a ~ r ~ y ~}$}

In this article the author briefly pointed out the important tasks of medical rescuers resulting from the current legal status and presented the changes planned in this regard. As the essence of this article, the author has made the rights of medical rescuers, but they also paid attention to the financing of the benefits provided by medical rescue teams, which also required the issue of health care services financed by public funds, in particular the role of the National Health Fund. The most important in the context of both existing and proposed changes seems to be the approximation of the status of medical rescuers to doctors or nurses, midwives, mainly due to the obligation imposed on them to keep professional secrets or keep medical records.

Key words: NFZ, medical rescue, health, health services.

\section{ОСУЩЕСТВ ЯЕННЫЕ И ПРОЕКТИРОВАННЫЕ ИЗМЕНЕНИЯ В ПОЯЬСКОМ РЕГУ ЛИРОВАНИИ КАСАТЕДЬНО СПАСАТЕЛЬНОЙ МЕДИЦИНСКОЙ СЛУЖБЫ - ИЗБРАННЫЕ ВОПРОСЫ}

\section{P е 3 ю м е}

В данной разработке авторы в сжатой форме указали на существенные задания медицинских спасателей, которые возникают из актуального обязательного правового статуса, а также представиди проектируемые в этой сфере изменения. Как основное данной статьи авторы обработали полномочия медицинских спасателей, но обратили также внимание на финансирование услуг, которые предоставляют службы медицинской помощи, что требовало также довести к вопросам, связанным с медицинскими услугами, которые финансируются из публичных средств, в частности, при помощи Национального Фонда Здоровья (NFZ). Самое существенное, в контексте также как существующих, так и проектированных изменений по-видимому будет близкий статуса медицинских спасателей к врачами либо к медсестрам, акушеркам, а главное, в связи с наложенной на них обязанности сохранения профессиональной тайны или ведения медицинской документации.

Кдючевые слова: Национального Фонда Здоровья (NFZ), медицинская помощь, здоровье, оздоровительные услуги 